\title{
Integrated Reporting as a Tool for Communicating with Stakeholders Advantages and Disadvantages
}

\author{
Iwona Matuszyk ${ }^{1}$, and Bartosz Rymkiewicz ${ }^{1, *}$ \\ ${ }^{1}$ AGH University Science and Technology, A. Mickiewicza Av. 30, 30-059 Krakow, Poland
}

\begin{abstract}
Financial and non-financial reporting from the beginning of its existence is the primary source of communication between the company and a wide range of stakeholders. Over the decades it has adapted to the needs of rapidly changing business and social environment. Currently, the final link in the evolution of organizational reporting, such as integrated reporting, assumes integration and mutual connectivity to both financial and non-financial data. The main interest in the concept of integrated reporting comes from the value it contributes to the organization. Undoubtedly, the concept of integrated reporting is a milestone in the evolution of organizational reporting. It is however important to consider whether it adequately addresses the information needs of a wide range of stakeholders, and whether it is a universal tool for communication between the company and its stakeholders. The aim of the paper is to discuss the advantages and disadvantages of the concept of integrated reporting as a tool for communication with stakeholders and to further directions of its development. The article uses the research methods such as literature analysis, the content analysis of the corporate publications and comparative analysis. Key words - organization reporting, integrated reporting, communication with stakeholders.
\end{abstract}

\section{Introduction}

Organizational reporting has been an essential tool for communication between the company and stakeholders since its inception. However, rapid social and economic changes lead to changes in the expectations of stakeholders. In order to meet these expectations organizational reporting is constantly evolving. Over the years, companies have been expanding the scope of disclosures by multiplying reports related to various spheres of the organization's activity. Among others, reports have been created on marketing, social, environmental, and sustainable development issues, as well as on compliance with the principles of corporate governance and many others. Excessive multiplication of corporate publications, often large in size, can sometimes lead to counterproductive effects. A decrease in the effectiveness of the information provided may lead to disruption of the organization's informational role of reporting. An international consultation has resulted in a modern concept of reporting, i.e., by integrating financial and non-financial data, with the latter being frequently scattered. One comprehensive,

\footnotetext{
Corresponding author: bartosz.rymkiewicz@wp.pl
} 
integrated, report appeared instead of many reports so far ${ }^{1}$. Integrated reporting is now the final link in the evolution of organization reporting and a milestone in its development. However, it should be considered whether it adequately meets the information needs of a wide range of stakeholders. As a consequence, doubts are raised whether such approach fulfils its fundamental role as a universal tool of communication between the company and its stakeholders.

The aim of this paper is to consider the advantages and disadvantages of integrated reporting as a tool for communication with stakeholders and to further development of the concept. The article uses research methods, i.e., literature analysis of the subject, analysis of corporate publications and comparative analysis.

\section{The problems of the traditional organization's reporting}

Economic and social reality are characterized by high levels of changes and dynamics. Increasing levels of globalization, opening of markets and technological development, as well as changes in lifestyles, all have impacted on methods and tools of communication with stakeholders. Nowadays, enterprises have a vast array of tools and methods of communication with stakeholders. This ranges from direct communication, to traditional media and social media popular in recent years. Of course, none of them is perfect and is not able to fully meet the expectations of all stakeholder groups. One of the oldest and most informative is organizational reporting. However, as economic reality is not static, organizational reporting is also changing.

E. Walińska [12] distinguished five stages of development in the company reporting, starting with a simple financial statement containing only financial data, supplementing it with non-financial information as supplementary information, developing an annual report covering additionally non-financial information, supplementing the annual report with the comments of the management board, ending with the preparation of additional reports, i.e., environmental, social and sustainable development report. All these phases of development were connected with changes in social expectations and the emergence of modern management concepts, such as the concept of corporate social responsibility or the concept of sustainable development, which in their scope also included information to stakeholders about the positive and negative effects of the entire organization's activity [7]. An extensive reporting of an organization, consisting of multiple reports covering only parts of the activity and containing data that are not interconnected, does not fulfil its purpose of communicating with a wide range of stakeholders in an appropriate and effective way. Multiplication of reports and their growing size lead to communication disturbances with stakeholders, while the large dispersion of information makes it difficult to find and analyze it.

The literature on the subject is widely criticized for the traditional form of organizational reporting, in particular financial reporting, which is an obligatory element. E. Szczepankiewicz points out that financial reporting in its current form does not provide information on the business perspectives, i.e., on types of risks and on threats related to the organization's activities, as well as to the investments and projects carried out, environment, social responsibility and environmental activities and intangible factors affecting the value of the company [13].

E. Walińska et al. [6] points out that traditional financial reporting does not provide the key information expected by investors, i.e., increased transparency, the scope of information presented, information enabling the preparation of financial situation forecasts, descriptive

1 The issues of integrated reporting were discussed in the literature of the subject, by among others such as: I.C. Chersan [1], R.G. Eccles, M. Krzus, S. Ribot [2], B. Bek-Gaik [3], D. Garstecki [4, 5], E. Walińska, B. Bek-Gaik, J. Gad, B. Rymkiewicz [6], J. Samelak [7], I. Matuszyk [8], B. Bek-Gaik, B. Rymkiewicz [9], B. Rymkiewicz, I. Matuszyk [10, 11] 
information and voluntary disclosures, and does not meet the expectations of other stakeholder groups.

Key weaknesses of the traditional financial statements pointed out by ICAEW [14] are: failure to adequately meet user needs, focus on historical data and on indicators rather than on non-financial indicators of future financial success, focus on reliable asset measurement rather than on intangible assets and knowledge that underpins the success of a modern enterprise, focus on aggregated data and focus on the short-term approach, the existence of a gap between data held by managers and information available to investors.

According to B. Bek-Gaik [3] the drawbacks of traditional financial reporting include: failure to meet the information needs of all stakeholders, limited information on factors influencing the creation of value, difficulties in interpretation, complexity, lack of coherence, limited recognition of some resources, lack of a business model, lack of information on key success factors and strategic plans, inability to determine the market value of the company.

The criticism of the organization's traditional reporting, presented in the literature of the subject, which is based on mandatory financial statements, indicates that changes are necessary. Until now the reporting format has required a number of changes in order to adapt it to the information needs of a wide range of stakeholders. A modern concept of integrated reporting can be the solution to address many, if not all, of the problems and shortcomings of traditional reporting by an organization.

\section{The concept of integrated reporting}

As mentioned earlier, integrated reporting is a modern solution that allows to eliminate existing weaknesses in the organization's traditional reporting. It is aimed at communication with a wide range of stakeholders [13], which is a response to the most frequent allegations that the information needs of a wide range of stakeholders are not met. This is an undeniable evolution of the approach, since the organizations traditional reporting has been focused mainly on large entities, investors and shareholders, while integrated reporting is addressed to all stakeholders, both internal (employees, shareholders) and external (counterparties, customers, social organizations, local communities, etc.).

The Integrated Report integrates and interconnects financial and non-financial information in a single comprehensive report. This allows to link the most relevant (from the point of view of both the company and a wide range of stakeholders) information about the entity, which until now has been dispersed in many different reports (e.g., management commentary, social report or environmental report) [6].

The main objectives of integrated reporting are: increasing the quality of information available to capital donors (improving the effectiveness of capital allocation), promoting a more coherent and effective approach to corporate reporting (in particular by disclosing information relevant for the organization's ability to create value over time), increasing responsibility for the capital base (not only in terms of financial capital, but also production, intellectual, human, social, relational and natural capital) and supporting integrated thinking (focusing on actions leading to creation value over time) [15]. Focusing on the value creation process is a particularly important feature of integrated reporting. The literature also describes an integrated report as a 'value report' [12].

In order to unify the concept of integrated reporting, the International Integrated Reporting Council in December 2013 developed the The International $<$ IR $>$ Framework [15]. The basic objective of the Framework is to "establish Guiding Principles and Content Elements that govern the overall content of an integrated report, and to explain the fundamental concepts that underpin them". The Framework includes the basic principles of preparing the report, i.e., strategic focus and future orientation, connectivity of information, stakeholder relationships, materiality, conciseness, reliability and completeness and consistency and comparability. 
These principles concern two fundamental issues, the quality of the information disclosed (e.g., materiality, conciseness, reliability and completeness) and the content of the report (e.g., strategic focus and future orientation, connectivity of information, stakeholder relationships), which should be defined by taking into account the information needs of a wide range of stakeholders. All of these principles are of key importance for proper communication with stakeholders. In addition to the principles, the Framework also sets out the basic elements that should be adequately covered by an integrated report. These elements include: organizational overview and external environment, governance, business model, risk and opportunities, strategy and resource allocation, performance, outlook, basis of preparation and presentation, general reporting guidance. All these elements should be interconnected, which is undoubtedly an innovative and conducive solution for the analysis of the whole organization. The most important element of the report's content is the business model, which presents in the greatest degree the value-creation process over time.

The Integrated Reporting Framework is a guideline for enterprises on how to properly prepare an integrated report. The postulates presented in the Framework significantly eliminate imperfections of traditional reporting, in particular regarding the improvement of communication with stakeholders.

\section{Integrated reporting as a modern tool for communication with stakeholders}

It has already been demonstrated that the organization's traditional reporting cannot fully meet the information needs of a wide range of stakeholders. Seeking a new way of communicating with stakeholders has led to the creation of an integrated reporting concept. However, can integrated reporting became a universal and modern tool for communication with stakeholders? We should consider what the main advantages of this form of communication are and if it is not without disadvantages.

Consideration of the benefits of integrated reporting should start with the scope of disclosures. The key issues are non-financial information, in particular information referring to the concept of management aimed at balancing social and environmental economic effects, i.e. the concept of corporate social responsibility and sustainable development. The disclosure of information on social, economic and environmental activities undertaken, the implementation of the concept of corporate social responsibility or sustainable development, management systems and other non-financial information may be an element of building the economic and social value of the enterprise to a much greater extent than traditional material resources [13]. The data on traditional material resources cannot represent the full potential of the organization. Integrated reporting aims to present not only financial, production and natural capital, that is capital that can be easily recorded and described, but also human, intellectual, and social and relational capital, where the true value of a company is hidden. However, the organization without the knowledge and experience of employees, know-how, procedures, patents, etc., is unable to compete effectively on the market.

It should be noted, therefore, that the disclosure of such information is an advantage on the one hand, and a disadvantage on the other. First of all, it is extremely difficult and timeconsuming to collect, analyze and process data on intellectual, human and relational capital for the purpose of preparing a report. Some elements are difficult to identify and describe. There is also a problem with their inclusion in the accounts (although the integrated reporting vision requires linking financial and non-financial data). Secondly, such information is usually heavily guarded by the company against market opponents, because it constitutes an important element in building a competitive advantage.

Nowadays in the era of enormous amount of information, the access to information is not the most important element. Much more important than quantity is its quality. As indicated by 
E. Szczepankiewicz, an integrated report prepared in an appropriate manner, especially with regard to the quality and reliability of information (reliable, timely, comprehensive, clear and comprehensible) and presenting information on activities for the benefit of society may constitute a basic tool for communication with stakeholders [13].

The key to ensuring the quality of the information published, especially its reliability and veracity, should be their audit, preferably by independent external certified bodies. This is currently problematic, as the audit of integrated reports is not regulated by law. It seems that the introduction of such an obligation could significantly increase confidence in the published data and at the same time increase the interest in integrated reporting.

A major problem with the concept of integrated reporting may arise from its early implementation. Managers have to face the challenge of obtaining information for the purpose of preparing a report. The management and accounting systems not always can provide all the necessary data [13]. The solution to this problem may be the introduction of the XBRL standard (Extensible Business Reporting Language), which allows automatization of reporting processes by linking it to existing financial and management accounting systems of the company ${ }^{2}$. Using the XBRL standard in the process of preparing the integrated report can also significantly decrease its costs by reducing the number of people involved in the process of preparing the report and time. Simultaneously, it enhances the communication possibilities of the report, making it easier to search and analyze data, as well as making them more comparable.

Disclosure of business model data may cause concern to managers, because is sensitive data that it is often a business secret. The decision to disclose this type of data may in extreme cases involve legal liability ${ }^{3}$.

From the perspective of communication with stakeholders, the integrated reporting concept has the great advantage of integrating financial and non-financial data into a single document. This increases the effectiveness of research and analysis of data by stakeholders, who until now had to search through numerous corporate publications.

Undoubtedly, the most important feature of the integrated report is the involvement of stakeholders in the process of defining the content of the integrated report. In preparing an integrated report, it is necessary to identify key stakeholders and their information needs. This is important because the company does not create value in isolation, but rather through relations with stakeholders [15]. Involving stakeholders in the process of defining the content of the report changes the role of the organization's reporting from a one-sided communication tool with stakeholders into a two-way tool - the report is an integrated response to legitimate information needs of stakeholders.

In conclusion, it is necessary to point out that the concept of integrated reporting has both advantages and disadvantages. Undoubtedly, it eliminates numerous imperfections of the organization's traditional reporting, however, some of the demands may turn out to be a threat to the company's existence. However, despite of this, it should be recognized that the integrated report is now the most comprehensive and accessible tool for communication with stakeholders.

\section{Summary}

More about the XBRL standard for integrated reporting: B. Rymkiewicz, I. Matuszyk [10].

For example, an act of unfair competition under Article 11 (1) of the Act of 16 April 1993 on Combating Unfair Competition (Journal of Laws 2003 No. 153 item 1503 with late amendments) is the transfer, disclosure or use of someone else's information constituting a business secret if it threatens or damages the interests of an entrepreneur. 
Nowadays, proper communication with stakeholders is becoming the basis for the existence of every organization. Rapid technological development, progress of globalization and social changes have led to the emergence of many modern forms of communication between the company and its stakeholders. Traditional organizational reporting has been slowly adapting to meet the legitimate information needs of a wide range of stakeholders. However, reporting is not a static creation, it constantly adapts to the needs of the environment. At present, the last step in the evolution chain of organization reporting is an integrated report that integrates and links financial and non-financial data into a single comprehensive document. Integrated reporting eliminates many of the shortcomings of traditional reporting, in particular by providing easier access to information, linking data, improving comparability, involving stakeholders in the process of defining the content of a report and many others. All these features are essential for building a proper channel of communication with stakeholders and bilateral communication, because by involving stakeholders in the process of defining the content of a report, an enterprise can respond to their legitimate expectations. Of course, integrated reporting is not without defects. Undoubtedly, disclosing an excessive amount of information, especially on the value creation process, may pose a certain threat to the functioning of the organization. However, the weaknesses identified in the future can be overcome by further evolution of the organization's reporting.

\section{References}

1. I.C. Chersan, Study on Practices and Tendencies in Integrated Reporting, Audit Financiar, 13 Issue 129, 91-101 (2015)

2. R.G. Eccles, M. Krzus, S. Ribot, Model of Best Practice in Integrated Reporting 2015, Journal of Applied Corporate Finance 27, no 2 (2015)

3. B. Bek-Gaik, Integrated Reporting - Selected Issues, Zeszyty Naukowe Uniwersytetu Szczecińskiego, Finanse, Rynki Finansowe, Ubezpieczenia 77, 479-491 (2015)

4. D. Garstecki, Integrated reporting in theory and practice of Polish companies [in:] J. Krasodomska, K. Świetla, Współczesne uwarunkowania sprawozdawczości i rewizji finansowej, Uniwersytet Ekonomiczny w Krakowie, 129-143 (2015)

5. D. Garstecki, Financial Data Disclosure in Chosen Companies Integrated Reports, Zeszyty Naukowe Uniwersytetu Szczecińskiego 873, Finanse, Rynki Finansowe, Ubezpieczenia 77, 503-512 (2015)

6. E. Walińska, B. Bek-Gaik, J. Gad, B. Rymkiewicz, Sprawozdawczość przedsiębiorstwa jako narzędzie komunikacji z otoczeniem. Wymiar finansowy i niefinansowy, Wydawnictwo Uniwersytetu Łódzkiego, Łódź (2015)

7. J. Samelak, Conceptual Framework of Integrated Report as a Form of CSR Reporting, Prace Naukowe Uniwersytetu Ekonomicznego we Wrocławiu 314, 155-165 (2013),

8. I. Matuszyk, Reporting Integrated in the Communication of the Enterprise with Surroundings, Zeszyty Naukowe Uniwersytetu Szczecińskiego 855, Finanse, Rynki Finansowe, Ubezpieczenia 74, no 2, 153-161 (2015)

9. B. Bek-Gaik, B. Rymkiewicz, Trends in the Development of Integrated Reporting in the Practice of Polish Listed Companies, Zeszyty Naukowe Uniwersytetu Szczecińskiego, Finanse, Rynki Finansowe, Ubezpieczenia 1 (79), 767-783 (2016)

10. B. Rymkiewicz, I. Matuszyk, The use of XBRL standard in integrated reporting [in:] L. Petrisin, P. Lebkovs'kij, Computer science, information techonologies and management systems: proceedings of the International scientific young scientist conference: 2017, April, 10th to 12th, Ivano-Frankivsk, Ukraine, 194-199 (2017) 
11. B. Rymkiewicz, I. Matuszyk, Integrated reporting as modern tool of communication with stakeholders [in:] V.L.Trusko, Problemy nedropol'zovaniâ: meždunarodnyj forumkonkurs molodyh učenyh: 19-21 aprelâ 2017 g.: sbornik naučnyh trubov, čast' I, 61-64 (2017)

12. E. Walińska, Integrated Report - Beginning of the End of Financial Statements?, Zeszyty Teoretyczne Rachunkowości, 82 (138), 151-165 (2015)

13. E. Szczepankiewicz, Evolution of Reporting Enterprises - Problems of Ensuring Comparability in Integrated Report on Sustainability and Socially Responsible Companies, Zeszyty Naukowe Uniwersytetu Szczecińskiego nr 832 Finanse, Rynki Finansowe, Ubezpieczenia 71, 135-148 (2014)

14. ICAEW, New Reporting Models For Business. Information for Better Markets initiative, https://www.icaew.com/-/media/corporate/files/technical/financial-

reporting/information-for-better-markets/ifbm/new-reporting-models-for-business2010-version.ashx (02.08.2017) (2010)

15. IIRC, The International $<$ IR $>$ Framework, https://integratedreporting.org/wp-content/uploads/2013/12/13-12-08-THE-

INTERNATIONAL-IR-FRAMEWORK-2-1.pdf (03.08.2017) (2013) 